\title{
THE IMPACT OF IRRIGATION IMPROVEMENT ACTIVITIES ON WATER AND SALT BALANCE FOR THE IRRIGATED LAND IN NEKLA CANAL (EL-BEHIRA GOVERNORATE)
}

\author{
Shaaban ${ }^{1 *}$ K.M., Galal ${ }^{2}$ M.E. and El-Gamal ${ }^{1}$ T.T.
}

[188]

1- Water Manag. Res. Inst., National Water Research Center, El-Qanater El-Khairiya, Qalyobia, Egypt

2- Soil Sci. Dept., Fac. of Agric., Ain Shams Univ., P.O. Box 68, Hadayek Shoubra, 11241 Cairo, Egypt

Received 4 August, 2019

Accepted 22 October, 2019

\section{ABSTRACT}

Three representative mesqas, i.e. Arfa Mousa at the head, Elafeer2 at the middle and Elbanna at the tail of Nekla canal. El-Behara Gov., were selected to evaluate the impact of the implementation of activities and processes of field irrigation system development on crop yield, water saving, water productivity, water and salt balance.

Results indicated slight increases in yield of the tested crops either irrigated from head - Arfa Mouse, middle - Elafeer2 or Tail - Elbanna mesqas. The average increases were about $6.98,5.99$ and $7.19 \%$ respectively. The average increases in crop water productivity were about 19.9, 19.5 and $20.0 \%$ for crops irrigated from the three mesqas respectively. The average increases in crop water productivity for wheat, rice, Egyptian clover, cantaloupe and watermelon pulp as affected by field irrigation system development were about 15.3, $21.5,22.9,18.5$ and $20.6 \%$ respectively. The average increases in water saving were about 10.8 , 11.2 and $10.6 \%$ for crops irrigated from the three tested meqas respectively. The average increases in water saving for wheat, rice, Egyptian clover, cantaloupe and watermelon pulp as affected by field irrigation system development were about 7.36, 12.9, 13.7, 10.6 and $9.88 \%$ respectively.

Results revealed that the net water balance (NWB) values decreased to about 87.6, 76.7 and $85.5 \%$ as affected by field irrigation system development relative to values before development equal to 100 for wheat, rice and Egyptian clover respectively under irrigation from Arfa Mousa mesqa at the head of Nekla canal. Similar results were also observed for wheat, rice and Egyptian clover irrigated from Elafeer2 at middle, and Elbanna mesqa at tail of Nekla canal. The average amount of salts added into soil cultivated with wheat, rice, Egyptian clover, cantaloupe and watermelon pulp were 800, 2350, 1255, 848 and 454 $\mathrm{kg} /$ Fed respectively before and 702, 1939, 1026, 719 and $388 \mathrm{~kg} /$ Fed after field irrigation system development. The average amount of salts removed from soil cultivated with wheat, rice, Egyptian clover, cantaloupe and watermelon pulp were $722,2456,1337,802$ and $454 \mathrm{~kg} /$ Fed respectively before development and 567, 2887, 591, 598 and $309 \mathrm{~kg} / \mathrm{Fed}$ after field irrigation system development.

It could be concluded that field irrigation system development has a positive effect on water saving, crop yield, water productivity and reducing salt accumulation in crop growth medium because field irrigation system development prevent seepage and weed growth increases in the developed mesqas and made water available all the time in the mesqa.

Keywords: Impact of irrigation; Salt balance; Nekla canal

\section{INTRODUCTION}

Egypt is unique among the nations of the world due to its main dependence upon a single water source, the River. Water demands in Egypt are growing rapidly due to the population explosion. The available fresh water per capita in Egypt dropped from 1893 cubic meters per person in 1959 to $800-900$ cubic meters in 2000 and tends to decline further to the values of 670 cubic meter by 2017 and 600 by 2025 (Malashkia, 2003 and MWRI, 2005). 
According to statistics, if the available fresh water per person drops below 1700 cubic meters, countries are considered as water stress regions. When per capita water use falls below 1000 cubic meters, countries undergo a chronic water scarcity, and less than 600 cubic meters of water per person would mean absolute water scarcity (Malashkia, 2003).

Egypt by year 2025 will face absolute water scarcity. The consumed water for irrigated agriculture is about $85 \%$ of the budget of MWRI while $10 \%$ are dedicated to services for the water supply and sanitation sector, and $5 \%$ attributed to the industrial sector (MWRI, 2005).

In the final report of the integrated irrigation improvement and management project (IIIMP), Simons et al (2012) reported that one of the main measures that have been taken to solve problems related to the distribution of water in the irrigation network is the application of continuous flow, as a replacement of the typical system of rotational flow. Water delivery services to the farmers are improved and the flexibility of the water management system is increased. The flow in the branch canal is determined by regulation of the discharge at the head of the canal, while taking into account the area served by the canal and its cropping pattern (i.e. crop water demands). Lifting of the water from the branch canal into the mesqa network has been centralized through an electric pump set at a single control point, with the purpose of increasing the equity of water distribution and reducing operational cost. Water losses through seepage from the mesqas are reduced by piping of the tertiary canals, also allowing for pressurized water delivery. Similar improvements have been made to under IIIMP, either by lining of the canals with brick and mortar or piping by low-pressure pipes up to the on-farm gate.

Inadequate water supply in a canal command area is a major limiting factor for sustainable crop production, as well as for adoption of the suitable crops. Satyendra et al (2013) indicated that the interventions were able to save a substantial amount of irrigation water (3-46\%) compared to surface methods, along with higher yields, a doubling of water productivity and more profits per $\mathrm{mm}$ of irrigation water. The study clearly showed that micro-irrigation in conjunction with an auxiliary reservoir should be recommended in canal-irrigated commands in order to improve water productivity and farmers' income in arid regions.
A significant volume of water was lost from small-scale irrigation systems in Ethiopia mainly because farmers' water application did not match crop needs (Derib et al 2011). They found that the high cost resulted by pumped irrigation positively affected water management by minimizing water losses and forced farmers to use deficit irrigation. Improving water productivity of small-scale irrigation requires integrated interferences including night storage mechanisms, optimal irrigation scheduling, empowerment of farmers to preserve canals and proper irrigation schedules. Noory et al (2011) pointed out that improving water management can decrease mean drainage water (22-48\%) and salts (30-49\%), compared with current water management without adverse effects on relative transpiration and root zone salinity.

In evaluation the effects of controlled irrigation and drainage on water productivity in paddy fields, Gao ShiKai et al (2018) found that the controlled irrigation and drainage reduced irrigation water without a significant impact on grain yields and increased the irrigation water productivity.

Water productivity can be expressed as agricultural production per unit volume of water. The United Nations, World water assessment programme calls for crop water productivity increases with the aim of reducing pressure to develop new supply sources or increasing water allocation to agriculture (UNESCO, 2009). FAO (2012) considers demand management as an important option to cope with water scarcity, with increasing agricultural water productivity as the single most important avenue for managing water demand in agriculture.

For wheat, rice and clover crops, the water productivity with respect to evapotranspiration is typically reported to be around $1.0-1.2 \mathrm{~kg} / \mathrm{m}^{3}$ for wheat (French and Schultz, 1984), 0.6 to 1.6 $\mathrm{kg} / \mathrm{m}^{3}$ for rice (Hsiao et al 1984) and 1.0-2.6 $\mathrm{kg} / \mathrm{m}^{3}$ for Egyptian clover (Grimes et al 1992).

The main objective of this work was to evaluate the impact of the implementation of the activities and processes of the development of field irrigation systems on crop yield, water productivity water saving, water balance and salt balance of some of the cultivated crops.

\section{MATERIALS AND METHODS}

The main objectives of this study were achieved by track the change in the characteristics of irrigation water and soil in different locations along Nekla canal representative by three mesqas, 

for the irrigated land in Nekla canal (El-Behira Governorate)

(Arfa Mousa at the head, Elafeer2 at the middle and Elbanna at the tail) before and after field irrigation system development. In addition, crops yield, water saving, crop water productivity were determined for some of the cultivated crops in the areas irrigated from these mesqas before and after the implementation of activities and processes of the development of the field irrigation systems.

The activities and processes of the development of the field irrigation system included the conversion of the unlined canals to buried pipes operating under water pressure head or to lined canals and changing the multiple lift points to a single lifting point at the head of the mesqa and the replacement of the hand control gates to the mechanical control gates for each canal feeder. In addition to the replacement of sharing water lifting machines with diesel or electric pump (lifting machines). The development of field irrigation system extended to establish of water users' associations at the branch canal level and the water council at the main canal level.

Water samples were collected several times from irrigation canals and mesqas under study to represent their properties at head, middle and tail before and after the development of field irrigation systems then subjected to chemical analyses (Table 1). Soil samples were taken using soil auger from investigated sites at the beginning and at the end of each crop growth season from the soil layers at $0-15,15-30,30-45$ and $45-60 \mathrm{~cm}$ depth. The collected soil samples were air dried and ground to pass through a $2 \mathrm{~mm}$ sieve, and then the different determinations of soil physical properties were conducted according to Klute (1986) and represented in Tables (2 and 3).

Table 1. Chemical analysis of water samples taken from Arafa Mousa (AM) at the head, Elafeer2 (EF2) at the middle and Elbanna (EB) at the tail mesqas, before and after field irrigation system development

\begin{tabular}{|c|c|c|c|c|c|c|c|c|c|}
\hline \multirow{2}{*}{ Site } & & \multirow{2}{*}{$\mathrm{pH}$} & \multirow{2}{*}{$\begin{array}{c}E C \\
d S / m\end{array}$} & $\mathrm{Ca}^{2+}$ & $\mathbf{M g}^{2+}$ & $\mathrm{Na}^{+}$ & $\mathbf{K}^{+}$ & $\mathrm{Cl}^{-}$ & $\mathrm{SO}_{4}=$ \\
\hline & & & & \multicolumn{6}{|c|}{$\mathrm{meq} / \mathrm{l}$} \\
\hline AM & Before & 8.22 & 0.57 & 2.80 & 2.00 & 1.00 & 0.22 & 0.50 & 4.50 \\
\hline head & After & 8.15 & 0.53 & 1.90 & 1.40 & 1.45 & 0.77 & 0.50 & 4.00 \\
\hline \multicolumn{2}{|c|}{ Mean } & 8.19 & 0.55 & 2.35 & 1.70 & 1.23 & 0.50 & 0.50 & 4.25 \\
\hline \multirow{2}{*}{$\begin{array}{c}\text { EF2 } \\
\text { middle }\end{array}$} & Before & 8.13 & 0.57 & 2.33 & 2.00 & 1.00 & 0.47 & 0.50 & 4.00 \\
\hline & After & 7.80 & 0.54 & 2.25 & 1.50 & 1.00 & 0.77 & 0.50 & 4.10 \\
\hline \multicolumn{2}{|c|}{ Mean } & 7.97 & 0.56 & 2.29 & 1.75 & 1.00 & 0.62 & 0.50 & 4.05 \\
\hline EB & Before & 8.20 & 0.57 & 2.45 & 2.00 & 1.00 & 0.22 & 0.50 & 4.00 \\
\hline tail & After & 8.03 & 0.55 & 1.90 & 1.72 & 1.00 & 0.97 & 0.50 & 3.85 \\
\hline \multicolumn{2}{|c|}{ Mean } & 8.12 & 0.56 & 2.18 & 1.86 & 1.00 & 0.60 & 0.50 & 3.93 \\
\hline \multirow[t]{2}{*}{ Mean } & Before & 8.18 & 0.57 & 2.53 & 2.00 & 1.00 & 0.30 & 0.50 & 4.17 \\
\hline & After & 7.99 & 0.54 & 2.02 & 1.54 & 1.15 & 0.84 & 0.50 & 3.98 \\
\hline
\end{tabular}


Table 2. Soil bulk density and some soil moisture parameters of the served area by Arafa Mousa (AM), Elafeer2 (EF2) and Elbanna (EB) mesqas, before field irrigation system development

\begin{tabular}{|c|c|c|c|c|c|}
\hline Site & Soil depth & bulk density & \multicolumn{3}{|c|}{ Soil moisture parameters \% } \\
\cline { 4 - 6 } & $\mathbf{c m}$ & $\mathbf{g} / \mathbf{c m}^{3}$ & FC & PWP & TAW \\
\hline \multirow{4}{*}{ Arafa Mousa at head } & $00-15$ & 1.1 & 46.1 & 24.8 & 21.4 \\
& $15-30$ & 1.2 & 41.2 & 21.3 & 19.9 \\
& $30-45$ & 1.2 & 36.8 & 20.4 & 16.5 \\
& $45-60$ & 1.3 & 34.9 & 19.1 & 15.8 \\
\hline Mean & $\mathbf{0 0 - 6 0}$ & $\mathbf{1 . 2}$ & $\mathbf{3 9 . 8}$ & $\mathbf{2 1 . 4}$ & $\mathbf{1 8 . 4}$ \\
\hline \multirow{3}{*}{ Elafeer2 at middle } & $00-15$ & 1.1 & 46.5 & 25.3 & 21.2 \\
& $15-30$ & 1.1 & 40.2 & 21.8 & 18.3 \\
& $30-45$ & 1.3 & 38.3 & 20.8 & 17.5 \\
& $45-60$ & 1.3 & 34.3 & 18.6 & 15.6 \\
\hline Mean & $\mathbf{0 0 - 6 0}$ & $\mathbf{1 . 2}$ & 39.8 & $\mathbf{2 1 . 6}$ & $\mathbf{1 8 . 2}$ \\
\hline \multirow{3}{*}{ Elbanna at tail } & $00-15$ & 1.1 & 46.7 & 25.4 & 21.3 \\
& $15-30$ & 1.2 & 40.4 & 21.9 & 18.4 \\
& $30-45$ & 1.2 & 37.2 & 20.2 & 17 \\
\hline Mean & $45-60$ & 1.3 & 34.2 & 18.6 & 15.6 \\
\hline
\end{tabular}

Table 3. Particales size distribution of the served area by Arafa Mousa (AM), Elaffaira2 (EF2) and Elbanna (EB) mesqas, before field irrigation system development

\begin{tabular}{|c|c|c|c|c|c|}
\hline \multirow{2}{*}{ Site } & Soil depth & \multicolumn{3}{|c|}{ Particales size distribution - \% } & \multirow{2}{*}{ Texture } \\
\cline { 3 - 5 } & cm & Sand & Silt & Clay & \\
& $00-15$ & 13.4 & 31.3 & 55.3 & Clay \\
& $15-30$ & 21.3 & 29.1 & 49.6 & Clay \\
Arafa Mousa at head & $30-45$ & 22.1 & 31.2 & 46.7 & Clay \\
& $45-60$ & 23.1 & 34.2 & 42.7 & Clay \\
\hline Mean & $00-60$ & 20.0 & 31.5 & 48.6 & Clay \\
\hline & $00-15$ & 12.3 & 33.3 & 54.4 & Clay \\
Elafeer2 at middle & $15-30$ & 20.2 & 34.2 & 48.6 & Clay \\
& $30-45$ & 20.4 & 34.5 & 45.1 & Clay \\
& $45-60$ & 21.1 & 35.7 & 43.2 & Clay \\
\hline Mean & $00-60$ & 18.5 & 34.4 & 47.8 & Clay \\
\hline & $00-15$ & 13.8 & 31 & 55.2 & Clay \\
Elbanna at tail & $15-30$ & 20.9 & 34.3 & 44.8 & Clay \\
& $30-45$ & 21.7 & 38.7 & 39.6 & Clay \\
& $45-60$ & 22.1 & 39.7 & 38.2 & Clay \\
\hline Mean & $00-60$ & 19.6 & 35.9 & 44.5 & Clay \\
\hline
\end{tabular}



for the irrigated land in Nekla canal (EI-Behira Governorate)

Electrical conductivity values (EC) in $\mathrm{dS} / \mathrm{m}$ were measured in the collected water samples or in the extract of saturated soil paste using electrical conductivity meter according to the method described by (Jackson, 1958).

Water application at mesqa field level is calculated based on the discharge from the pumps and the operation hours of this pump. The calibrate the pumps depends on the type of this pump either improved (fixed) or unimproved (movable) pumps. In the unimproved pumps, where water pumping freely to farm canal (Marwa), flumes are used to measure discharge from pumps. In this method, the discharge is defined based on the water depths at the upstream $(\mathrm{Ha})$ and the downstream $(\mathrm{Hb})$ of the cut throat flume. The discharge can be obtained from the corresponding tables based on the coefficient $C$ that is calculated using the following equation described by Water measurement manual, USA (2001):

$$
C=(H a-H b) / H a
$$

In improved mesqas, the ultrasonic flow meter is used to measure the discharge, with reflective type (V). In type (V), both transducers mounted on one side of the pipe, and the distance between them is defined based on the characteristics of the pipelines and the measured liquid. The flow is recorded in (lit/sec). The flow from the pump depends on the pressure (head), and the pressure consists of suction head and delivery head. Suction head is related to the water level in the suction side. Delivery head depends mainly on the friction losses, and therefore, it depends on the opened valve(s). The head is measured around the pumps (suction and delivery heads) for different scenarios of opening valves to define the range of the flow from the pumps.

With the flow from the pump, the operation hours should be collected/recorded to define total water supply from the mesqa. The simple way to get the operation hours is to collect them manually. The operator of the mesqa record the daily starting and stopping hours of the pumps. Other time, advanced techniques are used to define such starting and stopping hours. A data logger that is connected to the electric circle is used for this purpose. The device is recording the situation (on/off) each time interval. The recorded data is analyzed to define the starting and the stopping time for each pump such recorded data.

Level and salinity values of water table are recorded automatically using automatic recorders. A recorder (Solinst) was used for this purpose. The recorder was installed inside a pipeline (piezometer). The time interval for recording the data is defined during the setup, and normally it is half an hour. The recorder is defining the water depth above its datum, and using the level of this datum, such depths could be converted into levels. The salinity is measured directly.

Weather data for the experimental site were obtained from Nekla agro-meteorological station. Monthly values of solar radiation, minimum, maximum and mean air temperature, relative humidity, wind speed, and pan evaporation $\left(R_{s}, T_{\min }, T_{\max }\right.$ and $T_{\text {mean }}, R H, U$ and $E_{p}$ respectively) are presented in Table (4). Where: $R_{s}$ is Solar radiation in $\left(\mathrm{MJ} / \mathrm{m}^{2} /\right.$ day), $T_{\max }$ is Maximum air temperature $\mathrm{C}^{\circ}$, $T_{\text {min }}$ is Minimum air temperature $\mathrm{C}^{\circ}$, $\mathrm{T}_{\text {mean }}$ is Average air temperature $\mathrm{C}^{\circ}$, $\mathrm{T}_{\text {dew }}$ is Dew point temperature in $\mathrm{C}^{\circ}, \mathrm{P}$ is Precipitation in $\mathrm{mm} /$ day, $\mathrm{U}$ is Wind speed in $\mathrm{km} / \mathrm{h}$ and $\mathrm{RH}$ is Relative humidity in \%.

Water Consumption for crops (WU) after or before field irrigation development was determined by tracking the change in the soil moisture content before each irrigation. Soil moisture content $(\theta \mathrm{g})$ was gravimetrically determined in soil sample taken before each irrigation from the active root zone $\left(D_{s}\right)$ at $0-60 \mathrm{~cm}$ depth (Hansen et al 1979). Field capacity $\left(\theta_{\mathrm{FC}}\right)$, permanent wilting point $\left(\theta_{\mathrm{PWP}}\right)$ and soil bulk density $\left(\rho_{s}\right)$ were determined according to Klute (1986). Seasonal crop water consumptive use for each of the studied crops (WU) in $\mathrm{mm}$ or $\mathrm{m}^{3} /$ feddan were calculated using the following equation:

$$
\begin{gathered}
W U=\sum((\theta F C-\theta g) / 100) \times\left(\rho_{s} / \rho_{w}\right) \times D_{s} \times 4200 \\
m^{3} / F e d
\end{gathered}
$$

Where: WU is crop water consumptive use of the tested values through growth season of each crop in $\mathrm{mm}$ or $\mathrm{m}^{3} / \mathrm{Fed}, \theta \mathrm{g}$ is soil moisture percentage before irrigation in $\%(w / w), \theta_{F C}$ is Soil field capacity in $\%(w / w), D_{s}$ is soil layer depth or active root zone in $\mathrm{m}, \rho_{\mathrm{s}}$ is soil bulk density in $\mathrm{g} / \mathrm{cm}^{3}$ and $\rho_{w}$ is water density in $\mathrm{g} / \mathrm{cm}^{3}$.

Change in soil moisture storage (CSMS) was gravimetrically determined in soil sample taken from active root zone before and after the development.

Water productivity (WP) is a simple ratio between crop yield in $\mathrm{kg} / \mathrm{m}^{2}$ and water consumptive use (WU) in $\mathrm{m}^{3} / \mathrm{m}^{2}$ as shown in the following equation (El-Bably et al 2015).

$$
W P=\text { Crop yield } / W U
$$


Table 4. Monthly agro-meteorological data recorded for El-Behaira - Nekla during 2017

\begin{tabular}{|c|c|c|c|c|c|c|c|c|}
\hline Months & $\mathbf{R}_{\mathbf{s}}$ & $\mathbf{T}_{\max }$ & $\mathbf{T}_{\min }$ & $\mathbf{T}_{\text {mean }}$ & $\mathbf{T}_{\text {dew }}$ & $\mathbf{R H}$ & $\mathbf{U}$ & $\mathbf{P}$ \\
\hline Jan & 12.4 & 17.6 & 5.97 & 10.9 & 3.54 & 61.2 & 3.80 & 0.00 \\
Feb & 15.2 & 20.0 & 6.71 & 12.4 & 4.94 & 60.6 & 3.90 & 0.00 \\
Mar & 19.8 & 24.1 & 10.1 & 16.3 & 5.95 & 51.5 & 5.90 & 0.00 \\
Apr & 23.7 & 28.5 & 12.2 & 19.9 & 6.58 & 43.5 & 5.10 & 68.1 \\
May & 27.2 & 33.4 & 16.8 & 24.7 & 9.40 & 39.1 & 1.70 & 0.00 \\
June & 29.6 & 36.6 & 19.8 & 28.0 & 12.6 & 39.4 & 1.30 & 0.00 \\
July & 29.1 & 38.6 & 22.1 & 29.92 & 15.5 & 42.3 & 1.20 & 0.00 \\
Aug & 26.9 & 37.1 & 22.2 & 29.0 & 16.7 & 47.4 & 1.40 & 0.00 \\
Sept & 23.6 & 30.5 & 15.5 & 22.2 & 11.3 & 45.3 & 3.00 & 0.00 \\
Oct & 18.9 & 29.5 & 16.3 & 22.2 & 11.4 & 51.2 & 3.10 & 0.00 \\
Nov & 14.0 & 24.3 & 12.2 & 17.4 & 8.98 & 58.4 & 3.20 & 0.00 \\
Dec & 10.4 & 21.3 & 10.3 & 14.9 & 7.92 & 63.5 & 4.00 & 0.00 \\
\hline Mean & $\mathbf{2 0 . 9}$ & $\mathbf{2 8 . 5}$ & $\mathbf{1 4 . 2}$ & $\mathbf{2 0 . 6}$ & $\mathbf{9 . 5 7}$ & $\mathbf{5 0 . 3}$ & $\mathbf{3 . 1 3}$ & $\mathbf{6 8 . 1}$ \\
\hline
\end{tabular}

In this work the actual crop water productivity was calculated as the ratio between crop yield in $\mathrm{kg} /$ Fed and applied irrigation water (AIW) in $\mathrm{m}^{3} /$ Fed.

\section{CWP = Crop yield $/ \mathrm{A} I W$}

Water balance considers water inflows and outflows from field. Water outflow components at field are crop water consumptive use, deep percolation, runoff, soil moisture storage change. The inflow components are applied irrigation water, effective rainfall, subsurface contributions and surface seepage flows. Subsurface contributions and surface seepage flows were considered zero. Storage change component is soil moisture change in active root zone. Process depletion components are actual evapotranspiration, outflow components are deep percolation, and surface runoff. Deep percolation was calculated from the difference between the total amount of water applied (irrigation application and rainfall) and actual consumptive use. Surface runoff was zero. Drainage outflows are often not measured (Molden, 1997), as more emphasis has been placed on knowledge of inflows to irrigation systems. Gross inflow is the total amount of water flowing into the field from rainfall and surface and subsurface sources. Net inflow is the gross inflow plus any changes in storage. If water is removed from storage over the time period of interest, net inflow is greater than gross inflow; if water is added to storage; net inflow is less than gross inflow. Net inflow water is either depleted, or flows out of the field of interest.

Salt balance was determined as a difference between average salinity of water, both rainfall and irrigation water were taken under consideration into the field and average salinity of drainage water before and after growing season. The following are the salt balance equations as described by Taylor (1996):

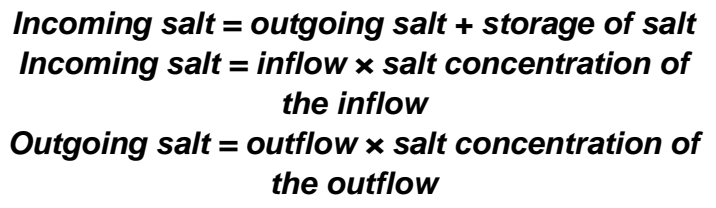

\section{RESULTS AND DISCUSSIONS}

The evaluation of the impact of the development of the field irrigation system in this study is based mainly on equitable distribution of irrigation water between the beneficiaries farmers by recognizing the change in crop yield, water saving, crop water productivity, water balance and salt balance for some crops before and after the development. 

for the irrigated land in Nekla canal (El-Behira Governorate)

\section{Effects of irrigation system development on applied irrigation water}

Results in Table (5) indicate the applied irrigation water (AIW) in $\mathrm{m}^{3}$ per irrigation and water saving of crops irrigated from Arafa Mouse at head, Elafeer at middle, and Elbanna mesqas at tail of Nekla canal before and after field irrigation system development. The applied irrigation water for wheat, rice, Egyptian clover, cantaloupe and watermelon pulp were ranged between 2169-2029, 6417-5592, 3408-2960, 2329-2072 and 1295-1161 for crops irrigated from Arfa Mousa at the head, 2224-2058, 6406-5589, 3407-2961, 2355-2089 and 1218-1077 for crops irrigated from Elafeer2 at the middle and 2184-2006, 6500-5652, 3504-2989, 2291-2291 and 1222-1128 $\mathrm{m}^{3} /$ Fed for crops irrigated from Elbanna mesqa at the tail of Nekla canal before - after field irrigation system development respectively.

It could be observed the differences in the irrigation water applied by the farmer for all crops before and after field irrigation system development. The applied irrigation water clearly decreased for all crops after field irrigation system development.

The highest difference between AIW before and after field irrigation system development was observed foe rice while the lowest diference was observed for wheat crop. These results may be due to prevailing water control through irrigation development.

Similar trend were also observed by Tariq (2010) who found that the relative water supply index varies from 1.66 to 2.02 during summer, whereas in winter it varies from 2.22 to 2.55 . Irrigation supplies were reliable over the whole growing season.

\section{Effects of irrigation system development on crop water use and applied irrigation water}

Water consumptive uses for some crops irrigated from Nekla canal were determined during growth season of each crop either irrigated from Arafa Mousa, Elafeer2 or Elbanna mesqas, Nekla canal, Elbehaira Gov. before and after irrigation system development and presented in Table (6).

The results showed that there is no specific trend to change the water consumption values of different crops due to the development of the field irrigation system. This may be due to the nature of these estimated WU values which based on crop growth and weather conditions during the different stages of growth and the homogeneous soil moisture in the root-zone and water control along irrigation canal.

As expected, all the estimated values of water consumption use (WU) of different crops are less than that of the values of applied irrigation water (AIW) by the farmer himself during the growing season. That is mean low on-farm irrigation efficiency. In fact, irrigation efficiency is usually reach to the highest whenever the difference between the estimated values of water consumption (WU) and applied irrigation water (AIW) during different stages of growth is in minimal. This is what should looking for.

Seasonal crop water use (WU) for wheat, rice, Egyptian clover, cantaloupe and watermelon pulp irrigated from the head (Arfa Mousa mesqa) were 1422-1465, 2976-2925, 2075-2036 1356-1376 and 822-795. While the WU by the same crops irrigated from the middle (Elafeer2 mesqa) were 1404-1438, 2944-2936, 2069-1977, -1373-1396 and 840-837 and 1438-1425, 2964-2943, 2041-2074, 13431325 and $789-845 \mathrm{~m}^{3} /$ Fed for crops irrigated from the tail (Elbanna mesqa) of Nekla canal before after field irrigation system development respectively (Table 6).

The observed irregular differences between the estimated water consumption (WU) values of the tested crops (Table 6) and the regular differences between the applied irrigation water (AIW) values for the same crops before and after field irrigation system development (Table 2) may ascribed to the positive effects of the development. One of the most important positive effects of irrigation system development is farmers' conviction at the head, middle and tail of irrigation canals of equitable water distribution.

\section{Effects of field irrigation system development on water saving}

Results obtained for the effects of field irrigation system development on water saving at deferent irrigations of crops were presented in Table (5). Water saving is calculated as the difference between applied irrigation water for crops before and after field irrigation system development. Data indicated that the increments in water saving were associated with the increases in the quantity of applied irrigation water for each irrigation during growth season. The highest values of water saving were observed at the sowing irrigations for each crops. 
Table 5. Average values of applied irrigation water (AIW) and water saving of crops irrigated from Nekla canal before and after field irrigation system development

\begin{tabular}{|c|c|c|c|c|c|c|c|c|c|}
\hline \multirow{4}{*}{ Crops } & \multicolumn{9}{|c|}{ Applied irrigation water in $\mathrm{m}^{3} / \mathrm{Fed}$} \\
\hline & \multicolumn{3}{|c|}{ Arafa Mousa } & \multicolumn{3}{|c|}{ Elafeer2 } & \multicolumn{3}{|c|}{ Elbanna } \\
\hline & Before & After & WS $\%$ & Before & After & WS $\%$ & Before & After & WS $\%$ \\
\hline & \multicolumn{9}{|c|}{ Field irrigation system development } \\
\hline Wheat & 2169 & 2029 & 6.45 & 2224 & 2058 & 7.46 & 2184 & 2006 & 8.15 \\
\hline Rice & 6417 & 5592 & 12.9 & 6406 & 5589 & 12.8 & 6500 & 5652 & 13.0 \\
\hline Eg. clover & 3408 & 2960 & 13.1 & 3407 & 2961 & 13.1 & 3504 & 2987 & 14.8 \\
\hline Cantaloupe & 2329 & 2072 & 11.0 & 2355 & 2089 & 11.3 & 2291 & 2076 & 9.4 \\
\hline Watermelon pulp & 1295 & 1161 & 10.3 & 1218 & 1077 & 11.58 & 1222 & 1128 & 7.69 \\
\hline
\end{tabular}

Table 6. Seasonal crop water use (WU) of some crops irrigated from Arafa Mousa at the head, Elafeer2 at the middle and Elbanna mesqas at the tail of Nekla canal, Elbehaira Gov. before and after irrigation system development

\begin{tabular}{|l|c|c|c|c|c|c|}
\hline \multirow{3}{*}{ Crops } & \multicolumn{6}{|c|}{ Crop water consumptive use in $\mathbf{m}^{3}$ /Fed } \\
\cline { 2 - 7 } & \multicolumn{2}{|c|}{ Arafa Mousa } & \multicolumn{2}{c|}{ Elafeer2 } & \multicolumn{2}{c|}{ Elbanna } \\
\cline { 2 - 7 } & Before & After & Before & After & Before & After \\
\cline { 2 - 7 } & \multicolumn{6}{|c|}{ Field irrigation system development } \\
\hline Wheat & 1422 & 1465 & 1404 & 1438 & 1438 & 1425 \\
Rice & 2976 & 2925 & 2944 & 2936 & 2964 & 2943 \\
Egyptian clover & 2075 & 2036 & 2069 & 1977 & 2041 & 2074 \\
Cantaloupe & 1356 & 1371 & 1373 & 1396 & 1343 & 1325 \\
Watermelon pulp & 822 & 795 & 840 & 837 & 789 & 845 \\
\hline
\end{tabular}

A substantial increases in water saving for all the tested crops irrigated from Arafa mousa at the head, Elafeer2 at the middle and Elbanna meaqa's at the tail of Nekla canal as affected by field irrigation system development. The average increases in water saving were about $10.8,11.2$ and $10.6 \%$ for crops irrigated from the three tested meqas respectively. These results are in agreement with that obtained by Radwan (2017) who concluded that the expected minimum, maximum, and average annual water saving from improved on-farm irrigation projects in Egypt are about 2.6, 6.72, and 4.67, respectively.

The average increases in water saving for wheat, rice, Egyptian clover, cantaloupe and watermelon pulp as affected by field irrigation system development were about 7.36, 12.9, 13.7, 10.6 and $9.88 \%$ respectively (Table 5 ). The average in- creases in water saving for wheat, rice, Egyptian clover, cantaloupe and watermelon pulp as affected by field irrigation system development were about $7.36,12.9,13.7,10.6$ and $9.88 \%$ respectively.

Effects of field irrigation system development on crop yield and water productivity

The yields of the tested crops were determined from the field data collected through the farmers' interviews. Results obtained for the effects of field irrigation system development.on crop yield and crop water productivity (CWP). Concerning crop yield as affected by field irrigation system development. Results in Table (7) indicated a slight increases in yield of the tested crops either irrigated from head - Arfa Mouse, middle - Elafeer2 or Tail - 

for the irrigated land in Nekla canal (EI-Behira Governorate)

Elbanna mesqas. The average increases were about $6.98,5.99$ and $7.19 \%$ respectively. The average relative increases in crop yield of wheat, rice, Egyptian clover, cantaloupe and watermelon pulp as affected by field irrigation system development were about 6.84, 5.83, 6.11, 6.01 and $6.68 \%$ respectively. These increase in crop yield may be attributed to the development of field irrigation system and enhanced water allowance. This result is in agreement with that obtained by Tariq (2010) who found a significant increase in crop yield as a response to irrigation systems modernization. Date showed that the expected improvment in water distribution equity after field irrigation system development was more effective in increasing crop yield irrigated from the tail of Nekla canal (Elbanna mesqa). This increase in crop yield was more pronounced for wheat, Egyptian clover and watermelon pulp. Crop water productivity, as defined by Molden, et al (2010) is the ratio of crop yield or crop value, to a selected measure of water consumed, applied, or evaporated in the process of growing a crop. In this work crop water productivity in $\mathrm{kg} / \mathrm{m}^{3}$ is calculated by deviding the crop yield in $\mathrm{kg} / \mathrm{Fed}$ on applied irrigation water in $\mathrm{m}^{3} /$ Fed.

Data in Table (7) revealed a substaintial increases in crop water productivity for all the tested crops irrigated from Arafa Mousa at the head, Elafeer2 at the middle and Elbanna meaqa's at the tail of Nekla canal as affected by field irrigation system development. The average increases in crop water productivity were about 19.9, 19.5 and $20.0 \%$ for crops irrigated from the three meqas respectively. The average increases in crop water productivity for wheat, rice, Egyptian clover, cantaloupe and watermelon pulp as affected by field irrigation system development were about 15.3, 21.5, 22.9, 18.5 and $20.6 \%$ respectively. The results of crop water productivity (CWP) found in this work are in agreement with that obtained by French and Schultz, (1984) for wheat, Hsiao et al (1984) for rice and Grimes et al., (1992) for clover.

The increases in crop yield and crop water productivity may be due to the positive effects of field irrigation system development on regular availability of water in the irrigation canals and the ease of the application by the farmers with more accuracy and with less effort, which ultimately lead to improve rationalize the use of water resources. It is worthy to mentioned that, Ashour et al (2010) found that the positive effects of field irrigation development may be ascribed to the improvement process preventing seepage and weed growth increases. It also made water available all the time in the mesqa, better scheduling of irrigation and higher flow rate at the field level has also contributed to reduce the irrigation time. The irrigation time does not only include the time when the pump is actually operating, but also the time to transport the water to the land. The losses are only due to evaporation from free water surface, which was also reduced by reducing mesqas' cross section.

\section{Effects of irrigation system development on water balance}

Results presented in Table (8 and 9) showed the water balance components and net water balance for crops irrigated from Arafa Mousa at the head, Elafeer2 at the middle and Elbanna mesqas at the tail of Nekla canal, Elbehaira Gov. before and after field irrigation system development. Results revealed that the net water balance (NWB) values decreased by about $87.6,76.7$ and $85.5 \%$ as affected by field irrigation system development relatve to values before development equal to 100 for wheat, rice and Egyptian clover respectively under irrigation from Arfa Mousa mesqa at the head of Nekla canal. Similar results were also observed for wheat, rice and Egyptian clover irrigated from Elafeer2 at middle, and Elbanna mesqa at tail of Nekla canal.

The average total inflow values for crops irrigated from Nekla canal before field irrigation system development were 2691, 6591, 3901, 2465 and $1365 \mathrm{~m}^{3} /$ Fed for wheat, rice, Egyptian clover, cantaloupe and watermelon pulp respectively. While the average total inflow values for crops irrigated from Nekla canal after development were 2405, 5741, 3363, 2219 and $1242 \mathrm{~m}^{3} /$ Fed for wheat, rice, Egyptian clover, cantaloupe and watermelon pulp respectively.

The average total water outflow values for crops irrigated from Nekla canal before field irrigation system development were 2192,6441, 3440, 2325 and $1245 \mathrm{~m}^{3} /$ Fed for wheat, rice, Egyptian clover, cantaloupe and watermelon pulp respectively. While the average total inflow values for crops irrigated from Nekla canal after development were 2031, 5611, 2969, 2079 and $1122 \mathrm{~m}^{3} /$ Fed for wheat, rice, Egyptian clover, cantaloupe and watermelon pulp respectively as shown in Table (9). 
Table 7. Applied irrigation water (AIW), crop yield and crop water productivity (CWP) of some crops irrigated from Arafa Mousa at the head, Elafeer2 at the middle and Elbanna mesqas at the tail of Nekla canal, El-Behaira Gov before and after field irrigation system development

\begin{tabular}{|c|c|c|c|c|c|c|c|c|}
\hline \multirow{4}{*}{$\begin{array}{c}\text { Area } \\
\text { in } \\
\text { Fed }\end{array}$} & \multirow{4}{*}{ Crop } & \multirow{2}{*}{\multicolumn{2}{|c|}{$\begin{array}{c}\text { AlW } \\
\mathrm{m}^{3} / \text { Fed }\end{array}$}} & \multirow{2}{*}{\multicolumn{2}{|c|}{$\begin{array}{c}\text { Yield } \\
\text { kg/Fed }\end{array}$}} & \multicolumn{3}{|c|}{ CWP } \\
\hline & & & & & & \multicolumn{2}{|c|}{$\mathrm{kg} / \mathrm{m}^{3}$} & \multirow[t]{2}{*}{$\%$} \\
\hline & & Before & After & Before & After & Before & After & \\
\hline & & \multicolumn{7}{|c|}{ Before and after field irrigation system development } \\
\hline \multicolumn{9}{|c|}{ Arafa Mousa mesqa at the head of Nekla canal } \\
\hline 17 & Wheat & 2169 & 2029 & 2700 & 2892 & 1.25 & 1.43 & 14.5 \\
\hline 20 & Rice & 6417 & 5592 & 4160 & 4320 & 4.59 & 5.5 & 19.2 \\
\hline 27 & Eg clover & 3408 & 2960 & 29433 & 31000 & 1.22 & 1.46 & 21.3 \\
\hline 5 & Cantaloupe & 2329 & 2072 & 4180 & 4530 & 1.79 & 2.19 & 21.8 \\
\hline 9 & Watermelon & 1295 & 1161 & 390 & 430 & 0.30 & 0.37 & 23.0 \\
\hline \multicolumn{8}{|c|}{ Elafeer2 mesqa at the middle of Nekla canal } & 19.9 \\
\hline 49 & Wheat & 2224 & 2058 & 2710 & 2870 & 1.22 & 1.39 & 14.4 \\
\hline 15 & Rice & 6406 & 5589 & 4124 & 4350 & 4.65 & 5.72 & 20.9 \\
\hline 19 & Eg clover & 3407 & 2961 & 29757 & 32000 & 1.21 & 1.47 & 23.7 \\
\hline 25 & Cantaloupe & 2355 & 2089 & 4200 & 4510 & 1.78 & 2.16 & 21.1 \\
\hline 10 & Watermelon & 1218 & 1077 & 386 & 400 & 0.14 & 0.16 & 17.2 \\
\hline \multicolumn{8}{|c|}{ Elbanna mesqa at the tail of Nekla canal } & 19.5 \\
\hline 21 & Wheat & 2184 & 2006 & 2678 & 2879 & 1.23 & 1.44 & 17.0 \\
\hline 15 & Rice & 6500 & 5652 & 4000 & 4330 & 4.52 & 5.5 & 24.5 \\
\hline 21 & Eg clover & 3504 & 2987 & 29398 & 31000 & 1.14 & 1.45 & 23.7 \\
\hline 3 & Cantaloupe & 2291 & 2076 & 4364 & 4470 & 1.90 & 2.15 & 13.0 \\
\hline 9 & Watermelon & 1222 & 1128 & 365 & 410 & 0.30 & 0.36 & 21.7 \\
\hline \multicolumn{8}{|c|}{ Average values for Nekla canal } & 20.0 \\
\hline 87 & Wheat & 2192 & 2031 & 2696 & 2880 & 1.23 & 1.42 & 15.3 \\
\hline 67 & Rice & 6441 & 2969 & 29529 & 31333 & 4.58 & 5.58 & 21.5 \\
\hline 50 & Eg clover & 3440 & 5611 & 4095 & 4333 & 1.19 & 1.46 & 22.9 \\
\hline 33 & Cantaloupe & 2325 & 2079 & 4248 & 4503 & 1.83 & 2.17 & 18.5 \\
\hline 28 & Watermelon & 1245 & 1122 & 380 & 413 & 0.25 & 0.30 & 20.6 \\
\hline
\end{tabular}

CWP: Crop water productivity 

for the irrigated land in Nekla canal (El-Behira Governorate)

Table 8. Water balance components for crops irrigated from Arafa Mousa at the head, Elafeer2 at the middle and Elbanna mesqas at the tail of Nekla canal, El-Behaira Gov. before and after field irrigation system development

\begin{tabular}{|c|c|c|c|c|c|c|c|c|c|}
\hline \multirow{2}{*}{ Crop } & & \multicolumn{4}{|c|}{ Inflow in $\mathrm{m}^{3} / \mathrm{Fed}$} & \multicolumn{3}{|c|}{ Outflow in $\mathrm{m}^{3} /$ Fed } & \multirow{2}{*}{$\begin{array}{c}\text { NWB } \\
\mathrm{m}^{3} / \text { Fed }\end{array}$} \\
\hline & & AIW & $\mathbf{R}$ & SS & Total & WU & Dp & Total & \\
\hline \multicolumn{10}{|c|}{ Arafa Mousa mesqa at the head of Nekla canal } \\
\hline \multirow[t]{2}{*}{ Wheat } & Before & 2169 & 277 & 150 & 2596 & 1445 & 724 & 2169 & 427 \\
\hline & After & 2029 & 244 & 130 & 2403 & 1445 & 584 & 2029 & 374 \\
\hline \multirow[t]{2}{*}{ Rice } & Before & 6417 & 0 & 150 & 6567 & 2940 & 3477 & 6417 & 150 \\
\hline & After & 5592 & 0 & 130 & 5722 & 2940 & 2652 & 5592 & 130 \\
\hline \multirow[t]{2}{*}{ Eg clover } & Before & 3408 & 291 & 170 & 3869 & 5058 & -1650 & 3408 & 461 \\
\hline & After & 2960 & 244 & 150 & 3354 & 5058 & -2098 & 2960 & 394 \\
\hline \multirow[t]{2}{*}{ Cantaloupe } & Before & 2329 & 0 & 140 & 2469 & 1348 & 981 & 2329 & 140 \\
\hline & After & 2072 & 0 & 140 & 2212 & 1348 & 724 & 2072 & 140 \\
\hline \multirow{2}{*}{$\begin{array}{c}\text { Watermelon } \\
\text { pulp }\end{array}$} & Before & 1295 & 0 & 120 & 1415 & 811 & 484 & 1295 & 120 \\
\hline & After & 1161 & 0 & 120 & 1281 & 811 & 350 & 1161 & 120 \\
\hline \multicolumn{10}{|c|}{ Elafeer2 mesqa at the middle of Nekla canal } \\
\hline \multirow[t]{2}{*}{ Wheat } & Before & 2224 & 276 & 150 & 2650 & 1428 & 796 & 2224 & 426 \\
\hline & After & 2058 & 244 & 130 & 2432 & 1428 & 630 & 2058 & 374 \\
\hline \multirow[t]{2}{*}{ Rice } & Before & 6406 & 0 & 150 & 6556 & 2936 & 3470 & 6406 & 150 \\
\hline & After & 5589 & 0 & 130 & 5719 & 2936 & 2653 & 5589 & 130 \\
\hline \multirow[t]{2}{*}{ Eg clover } & Before & 3407 & 291 & 170 & 3868 & 2024 & 1383 & 3407 & 461 \\
\hline & After & 2961 & 244 & 150 & 3355 & 2024 & 937 & 2961 & 394 \\
\hline \multirow[t]{2}{*}{ Cantaloupe } & Before & 2355 & 0 & 140 & 2495 & 1386 & 969 & 2355 & 140 \\
\hline & After & 2089 & 0 & 140 & 2229 & 1386 & 703 & 2089 & 140 \\
\hline \multirow{2}{*}{$\begin{array}{c}\text { Watermelon } \\
\text { pulp }\end{array}$} & Before & 1218 & 0 & 120 & 1338 & 840 & 378 & 1218 & 120 \\
\hline & After & 1077 & 0 & 120 & 1197 & 840 & 237 & 1077 & 120 \\
\hline \multicolumn{10}{|c|}{ Elbanna mesqa at the tail of Nekla canal } \\
\hline \multirow[t]{2}{*}{ Wheat } & Before & 2184 & 277 & 150 & 2611 & 1445 & 739 & 2184 & 427 \\
\hline & After & 2006 & 244 & 130 & 2380 & 1445 & 561 & 2006 & 374 \\
\hline \multirow[t]{2}{*}{ Rice } & Before & 6500 & 0 & 150 & 6650 & 2953 & 3547 & 6500 & 150 \\
\hline & After & 5652 & 0 & 130 & 5782 & 2953 & 2699 & 5652 & 130 \\
\hline \multirow[t]{2}{*}{ Eg clover } & Before & 3504 & 293 & 170 & 3967 & 2058 & 1446 & 3504 & 463 \\
\hline & After & 2987 & 244 & 150 & 3381 & 2058 & 929 & 2987 & 394 \\
\hline \multirow[t]{2}{*}{ Cantaloupe } & Before & 2291 & 0 & 140 & 2431 & 1340 & 951 & 2291 & 140 \\
\hline & After & 2076 & 0 & 140 & 2216 & 1340 & 736 & 2076 & 140 \\
\hline \multirow{2}{*}{$\begin{array}{c}\text { Watermelon } \\
\text { pulp }\end{array}$} & Before & 1222 & 0 & 120 & 1342 & 819 & 403 & 1222 & 120 \\
\hline & After & 1128 & 0 & 120 & 1248 & 819 & 309 & 1128 & 120 \\
\hline
\end{tabular}


Table 9. Average net water balance for crops grown on areas irrigated from Nekla canal, El-Behira Gov. before and after field irrigation system development

\begin{tabular}{|c|c|c|c|c|c|c|c|c|c|}
\hline \multirow{2}{*}{ Crop } & & \multicolumn{4}{|c|}{ Inflow in $\mathrm{m}^{3} /$ Fed } & \multicolumn{3}{|c|}{ Outflow in $\mathrm{m}^{3} /$ Fed } & \multirow{2}{*}{$\begin{array}{c}\text { NWB } \\
\mathrm{m}^{3} / \text { Fed }\end{array}$} \\
\hline & & AWI & $\mathbf{R}$ & CSMS & Total & WU & $D_{P}$ & Total & \\
\hline \multirow[t]{2}{*}{ Wheat } & Before & 2192 & 277 & 150 & 2619 & 1439 & 753 & 2192 & 427 \\
\hline & After & 2031 & 244 & 130 & 2405 & 1439 & 592 & 2031 & 374 \\
\hline \multirow[t]{2}{*}{ Rice } & Before & 6441 & 0 & 150 & 6591 & 2943 & 3498 & 6441 & 150 \\
\hline & After & 5611 & 0 & 130 & 5741 & 2943 & 2668 & 5611 & 130 \\
\hline \multirow[t]{2}{*}{ Eg. clover } & Before & 3440 & 292 & 170 & 3901 & 3047 & 393 & 3440 & 462 \\
\hline & After & 2969 & 244 & 150 & 3363 & 3047 & -77 & 2969 & 394 \\
\hline \multirow[t]{2}{*}{ Cantaloupe } & Before & 2325 & 0 & 140 & 2465 & 1358 & 967 & 2325 & 140 \\
\hline & After & 2079 & 0 & 140 & 2219 & 1358 & 721 & 2079 & 140 \\
\hline Watermelon & Before & 1245 & 0 & 120 & 1365 & 823 & 422 & 1245 & 120 \\
\hline pulp & After & 1122 & 0 & 120 & 1242 & 823 & 299 & 1122 & 120 \\
\hline
\end{tabular}

Assuming runoff $=0$

AIW: Applied irrigation water

R: Rainfall

CSMS: Change in soil moisture storage

Dp: Deep percolation = AIW - WU

Total water inflow $=$ AIW + Rainfall + Soil Storage

Total water outflow $=\mathrm{WU}+$ Runoff + Deep percolation

NWB: Net water balance $=$ Inflow - Outflow

\section{Effects of irrigation system development on salt balance}

Results in Table (10 and 11) show the salt balance components and net salt balance for the diferent crops grown on areas irrigated from Arafa Mousa at the head, Elafeer2 at the middle and Elbanna mesqas at the tail of Nekla canal, Elbehira before and after field irrigation system development. Results ravealed that salt balance in plant growth medium depends mainly on the quantity of salts added through applied irrigation water and partialy through the quantity of rainfall and salt removed mainly by leaching through drainage water.

As expected, the results showed that the amount of salts added (SA) to rice-cultivated soil irrigated from Arafa Mousa at the head, Elafeer2 at the middle or Elbanna mesqas at the tail of Nekla canal were higher before than after field irrigation system development.

While the amount of salts removed from ricecultivated soil irrigated from Arafa Mousa at the head, Elafeer2 at the middle or Elbanna mesqas at the tail of Nekla canal tail was lower before than after field irrigation system development.
The amount of salts removed (SR) from the cultivated land with wheat, Egyptian clover, cantaloupe and watermelon crops was higher before than after field irrigation system development. This may be attributed to the reduction in irrigation water associated with field irrigation system development which led to reduce the amount of salts added and reduce the amounts of salts removed from the soil.

Concerning This may be attributed to the large quantities of irrigation water that farmers added to soil cultivated with rice crop either before or after field irrigation system development where. The large quantatity of irrigation water may increase the amount of salt added and salt remove by leaching.

It could be observed from Table (10) that the average amount of salts added into soil cultivated with wheat, rice, Egyptian clover, cantaloupe and watermelon pulp were $800,2350,1255,848$ and $454 \mathrm{~kg} /$ Fed respectively under irrigation from Nekla canal before development and 702, 1939, 1026, 719 and $388 \mathrm{~kg} / \mathrm{Fed}$ after field irrigation system development. 

for the irrigated land in Nekla canal (El-Behira Governorate)

Table 10. Salt balance components for crops grown on soils irrigated from Arafa Mousa at the head, Elafeer2 at the middle and Elbanna mesqas at the tail of Nekla canal, El-Behira before and after field irrigation system development

\begin{tabular}{|c|c|c|c|c|c|c|c|c|c|}
\hline \multirow[b]{2}{*}{ Crop } & & \multicolumn{3}{|c|}{ Salt - IN } & \multicolumn{3}{|c|}{ Salt - OUT } & \multirow[b]{2}{*}{$\begin{array}{c}\text { NSB } \\
\mathrm{kg} / \mathrm{Fed}\end{array}$} & \multirow[b]{2}{*}{$\begin{array}{c}\text { RSR } \\
\% \\
\end{array}$} \\
\hline & & $\begin{array}{c}\text { AlW } \\
\mathrm{m}^{3} / \text { Fed }\end{array}$ & $\begin{array}{c}\text { TSS }_{\text {iw }} \\
\mathrm{mg} / \mathrm{l}\end{array}$ & $\begin{array}{c}\text { SA } \\
\mathrm{kg} / \text { Fed }\end{array}$ & $\begin{array}{c}Q_{\mathrm{dw}} \\
\mathrm{m}^{3} / \text { Fed }\end{array}$ & $\begin{array}{c}T^{2} S_{d w} \\
m g / l\end{array}$ & $\begin{array}{c}\text { SR } \\
\mathrm{kg} / \text { Fed }\end{array}$ & & \\
\hline \multicolumn{10}{|c|}{ Arafa Mousa mesqa at the head of Nekla canal } \\
\hline \multirow[t]{2}{*}{ Wheat } & Before & 2169 & 365 & 791 & 728 & 960 & 699 & 92 & 88 \\
\hline & After & 2029 & 346 & 701 & 588 & 960 & 564 & 137 & 80 \\
\hline \multirow[t]{2}{*}{ Rice } & Before & 6417 & 365 & 2341 & 3979 & 640 & 2547 & -206 & 109 \\
\hline & After & 5592 & 346 & 1933 & 3154 & 960 & 3028 & -1095 & 157 \\
\hline \multirow[t]{2}{*}{ Eg clover } & Before & 3408 & 365 & 1243 & 1350 & 960 & 1296 & -53 & 104 \\
\hline & After & 2960 & 346 & 1023 & 902 & 640 & 577 & 446 & 56 \\
\hline \multirow[t]{2}{*}{ Cantaloupe } & Before & 2329 & 365 & 850 & 981 & 832 & 816 & 33 & 96 \\
\hline & After & 2072 & 346 & 716 & 724 & 832 & 602 & 114 & 84 \\
\hline \multirow{2}{*}{$\begin{array}{l}\text { Watermelon } \\
\text { pulp }\end{array}$} & Before & 1295 & 365 & 472 & 484 & 1024 & 496 & -23 & 105 \\
\hline & After & 1161 & 346 & 401 & 350 & 1024 & 358 & 43 & 89 \\
\hline \multicolumn{10}{|c|}{ Elafeer2 mesqa at the middle of Nekla canal } \\
\hline \multirow[t]{2}{*}{ Wheat } & Before & 2224 & 365 & 811 & 796 & 960 & 764 & 47 & 94 \\
\hline & After & 2058 & 346 & 711 & 630 & 960 & 605 & 106 & 85 \\
\hline \multirow[t]{2}{*}{ Rice } & Before & 6406 & 365 & 2337 & 3470 & 640 & 2221 & 116 & 95 \\
\hline & After & 5589 & 346 & 1932 & 2653 & 960 & 2547 & -615 & 132 \\
\hline \multirow[t]{2}{*}{ Eg clover } & Before & 3407 & 365 & 1243 & 1383 & 960 & 1328 & -85 & 107 \\
\hline & After & 2961 & 346 & 1023 & 937 & 640 & 600 & 424 & 59 \\
\hline \multirow[t]{2}{*}{ Cantaloupe } & Before & 2355 & 365 & 859 & 969 & 832 & 806 & 53 & 94 \\
\hline & After & 2089 & 346 & 722 & 703 & 832 & 585 & 137 & 81 \\
\hline \multirow{2}{*}{$\begin{array}{c}\text { Watermelon } \\
\text { pulp }\end{array}$} & Before & 1218 & 365 & 444 & 378 & 1024 & 387 & 57 & 87 \\
\hline & After & 1077 & 346 & 372 & 237 & 1024 & 243 & 130 & 65 \\
\hline \multicolumn{10}{|c|}{ Elbanna mesqa at the tail of Nekla canal } \\
\hline \multirow[t]{2}{*}{ Wheat } & Before & 2184 & 365 & 797 & 731 & 960 & 702 & 95 & 88 \\
\hline & After & 2006 & 346 & 693 & 553 & 960 & 531 & 162 & 77 \\
\hline \multirow[t]{2}{*}{ Rice } & Before & 6500 & 365 & 2371 & 4062 & 640 & 2600 & -228 & 110 \\
\hline & After & 5652 & 346 & 1953 & 3214 & 960 & 3085 & -1132 & 158 \\
\hline \multirow[t]{2}{*}{ Eg clover } & Before & 3504 & 365 & 1278 & 1446 & 960 & 1388 & -110 & 109 \\
\hline & After & 2987 & 346 & 1032 & 929 & 640 & 595 & 438 & 58 \\
\hline \multirow[t]{2}{*}{ Cantaloupe } & Before & 2291 & 365 & 836 & 943 & 832 & 785 & 51 & 94 \\
\hline & After & 2076 & 346 & 717 & 728 & 832 & 606 & 112 & 84 \\
\hline \multirow{2}{*}{$\begin{array}{l}\text { Watermelon } \\
\text { pulp }\end{array}$} & Before & 1222 & 365 & 446 & 411 & 1024 & 421 & 25 & 94 \\
\hline & After & 1128 & 346 & 390 & 317 & 1024 & 325 & 65 & 83 \\
\hline
\end{tabular}


Table 11. Net Salt balance for the different crops grown on areas irrigated from Nekla canal, El-Behira before and after field irrigation system development

\begin{tabular}{|c|c|c|c|c|c|c|c|c|c|}
\hline \multirow[b]{2}{*}{ Crop } & & \multicolumn{3}{|c|}{ Salt - IN } & \multicolumn{3}{|c|}{ Salt - OUT } & \multirow[b]{2}{*}{$\begin{array}{c}\text { NSB } \\
\mathrm{kg} / \text { Fed }\end{array}$} & \multirow[b]{2}{*}{$\begin{array}{c}\text { RSR } \\
\% \\
\end{array}$} \\
\hline & & $\begin{array}{c}\text { AIW } \\
\mathrm{m}^{3} / \text { Fed }\end{array}$ & $\begin{array}{c}\text { TSS }_{i w} \\
\mathrm{mg} / \mathrm{l}\end{array}$ & $\begin{array}{c}\text { SA } \\
\mathrm{kg} / \text { Fed }\end{array}$ & $\begin{array}{c}Q_{\mathrm{dw}} \\
\mathrm{m}^{3} / \text { Fed }\end{array}$ & $\begin{array}{c}\text { TSS }_{\mathrm{dw}} \\
\mathrm{mg} / \mathrm{l}\end{array}$ & $\begin{array}{c}\text { SR } \\
\mathrm{kg} / \text { Fed }\end{array}$ & & \\
\hline \multicolumn{10}{|c|}{ Nekla canal } \\
\hline \multirow{2}{*}{ Wheat } & Before & 2192 & 365 & 800 & 752 & 960 & 722 & 78 & 90 \\
\hline & After & 2031 & 346 & 702 & 590 & 960 & 567 & 135 & 81 \\
\hline \multirow{2}{*}{ Rice } & Before & 6441 & 365 & 2350 & 3837 & 640 & 2456 & -106 & 104 \\
\hline & After & 5611 & 346 & 1939 & 3007 & 960 & 2887 & -948 & 149 \\
\hline \multirow{2}{*}{ Eg clover } & Before & 3440 & 365 & 1255 & 1393 & 960 & 1337 & -82 & 107 \\
\hline & After & 2969 & 346 & 1026 & 923 & 640 & 591 & 436 & 58 \\
\hline \multirow{2}{*}{ Cantaloupe } & Before & 2325 & 365 & 848 & 964 & 832 & 802 & 46 & 95 \\
\hline & After & 2079 & 346 & 719 & 718 & 832 & 598 & 121 & 83 \\
\hline \multirow{2}{*}{$\begin{array}{c}\text { Watermelon } \\
\text { pulp }\end{array}$} & Before & 1245 & 365 & 454 & 424 & 1024 & 435 & 20 & 95 \\
\hline & After & 1122 & 346 & 388 & 301 & 1024 & 309 & 79 & 79 \\
\hline \multicolumn{10}{|c|}{$\begin{array}{ll}\text { AIW: } & \text { Applied irrigation wa } \\
\text { TSS iw: } & \text { Total saluble salts o } \\
\text { Qdw: } & \text { Quantity of drainage } \\
\text { TSS }_{\text {dw }}: & \text { Total saluble salts o } \\
\text { SA: } & \text { Salt added } \\
\text { SR: } & \text { Salt removed } \\
\text { NSB: } & \text { Net salt Balance } \\
\text { RSR: } & \text { Relative salt remove }\end{array}$} \\
\hline
\end{tabular}

As shown in Table (10) the average amount of salts removed from soil cultivated with wheat, rice, Egyptian clover, cantaloupe and watermelon pulp were 722, 2456, 1337, 802 and $454 \mathrm{~kg} /$ Fed respectively under irrigation from Nekla canal beforedevelopment and 567, 2887, 591, 598 and 309 $\mathrm{kg} /$ Fed after field irrigation system development.

The relative net salts outflow or removed from the growth medium of the tested crops were in the descending order: Rice $>$ Egyptian clover $>$ Wheat $>$ Cantaloupe $>$ Watermelon pulp as affected by field irrigation system development Table (11).

It could be concluded that the investiment in irrigation modernization and improvement to make the water delivery system and its management flexible enough to take full advantage of new technologies and effective crop patterns so, it is very important and viable to continue and expand the irrigation improvement activities in the old land of Egypt.

It can recommend that under conditions of water scarcity that we are facing, the development of field irrigation is a must because it improves water management at the field level, increase agricultural productivity; overcomes problems of water distribution among farmers, saves of the irrigation water used and increases the value of water productivity. Besides, maximizing the benefits of return from the unit of land and water associated with economic, environmental and social aspects.

\section{REFERENCES}

Ashour M.A., El-Attar S.T., Amen K.A. and Abo El-Eyon H.M. 2010. Irrigation Improvement Iststem and its effect on water management in Beni Adi Village. J. of Engineering Sci., Assiut Univ., 38(6), 1345-1365.

Derib S.D., Katrien D., Amare H. and Tilahun A. 2011. Irrigation water productivity as affected by water management in a small-scale irrigation scheme in the Blue Nile basin, Ethiopia. (Special Issue: Improving water productivity of crop-livestock systems in drought-prone regions.). Experimental Agriculture; 2011. 47(Suppl. 1), 39-55. 

for the irrigated land in Nekla canal (El-Behira Governorate)

El-Bably A.Z., Abd El-Hafez S.A., Mahmoud and Samiha M.A. and Oud A.H. 2015. A New Conceptual Framework for Water Conservation Based on Addressing Water Balance, Crop Rotation and Economics. Int. J. of Water Resources and Arid Environments 4(2), 120127.

FAO 1992. Wastewater Treatment and use in Agriculture. Pescod MB. Irrigation and Drainage Paper 47. Food and Agricultural Organization (FAO), Rome, Italy.

French R.J. and Schultz J.E. 1984. Water use efficiency of wheat in a Mediterranean-type environment. I. The relation between yield, water use and climate. Australian J. Agric. Research 35, 743-764.

Gao S., Yu S., Wang M., Meng J., Tang S., Ding J., Li S. and Miao Z. 2018. Improving water productivity and reducing nutrient losses by controlled irrigation and drainage in paddy fields. Polish J. of Environmental Studies 27(3), 1049-1059.

Grimes D.W., Wiley P.L. and Sheesley W.R. 1992. Alfalfa Yield and Plant Water Relations with Variable Irrigation. Crop Sci., 32, 13811387.

Hansen V.W., Israelsen D.W. and Stringharm Q.E. 1979. Irrigation principle and practices, $4^{\text {th }}$ ed. John Wiley as sons, New York, USA.

Jackson M.L. 1958. Soil chemical analysis. Prentice Hall, Inc. Englewood Cliffs, N.J. Library of Congress, USA.

Klute A. 1986. Water retention: Laboratory methods. In: Klute, A., Ed., Methods of Soil Analysis, Part 1, Physical and Mineralogical Methods, ASA and SSSA, Madison, pp. 635-662.

Malashkia N. 2003. Social and environmental constrains to the irrigation water conservation measures in Egypt. Master thesis. Lund Univ., Sweeden.
MWRI 2005. Integrated water resources management plan, A Government report, Cairo, Egypt.

Molden D. 1996. Accounting for water use and productivity. SWIM Paper 1. International Irrigation Management, Colombo, Sri Lanka. Institute.

Noory H., Zee S.E.A.T.M. van der, Liaghat A.M., Parsinejad M. and Dam J.C. van 2011. Distributed agro-hydrological modeling with SWAP to improve water and salt management of the Voshmgir Irrigation and Drainage Network in Northern Iran. Agric. Water Management 98(6), 1062-1070.

Radwan H.G. 2017. Water saving from improved on-farm irrigation projects in Egypt. Int. J. of Scientific \& Engineering Research, 8(8), 871-883.

Simons G., Terink W., Badawy H., Eertwegh G. and Bastiaanssen W. 2012. Egypt: Assessing the Effects of Farm-Level Irrigation Modernization on Water Availability and Crop Yields Final Report (Summer 2011 and Winter 2011/2012) pp.1-127.

Tariq J.A. 2010. Improving operational performace and management of canal irrigation system using hydraulic modeling. PhD thesis, Center of excellence in water resources engineering, University of Engineering and Technology, Lahore, Pakistan. pp. 1-255.

Taylor S. 1996. Dryland salinity: introductory extension notes Edition, Department of Land and Water Conservation, Sydney, NSW.

UNESCO 2009. Water in a Changing World: The United Nations World Water Development Report 3. Paris: UNESCO Publishing, and London: Earthscan.

Water Measurement Manual 2001. A water resources technical publication. A guide to effective water measurement practices for better water management revised edition, U.S. Department of the Interior. Bureau of Reclamation, USA. 


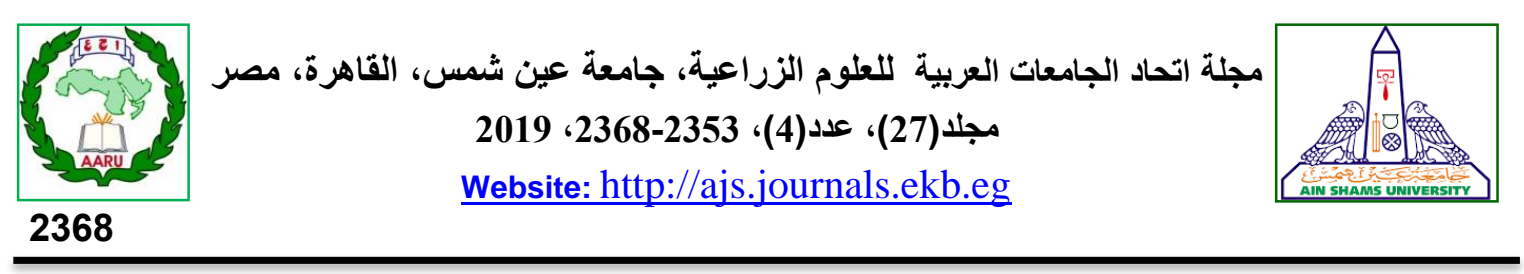

تأثير تطوير الرى على الاتزان المائى والملحى للأراضى المروية من ترعة نكلا بمحافظة البحيرة

[188]

\author{
خالد محمد شعبان 1" - محمد السيد جلال2 - طلعت طاهر الجمل 1 - مبان

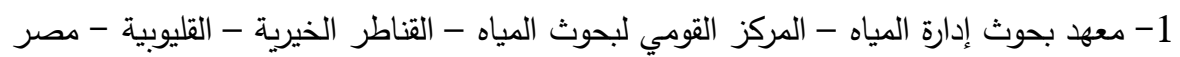

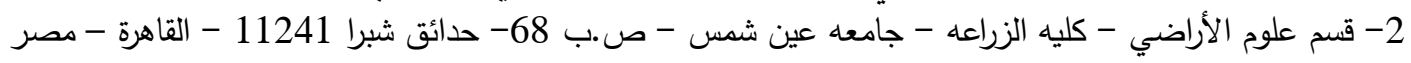

Received 4 August, 2019 Accepted 22 October, 2019

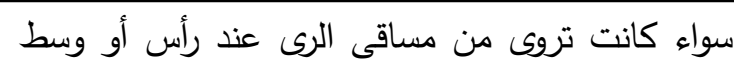

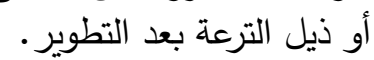

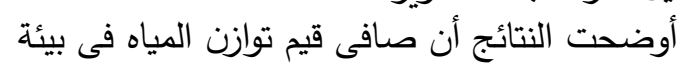

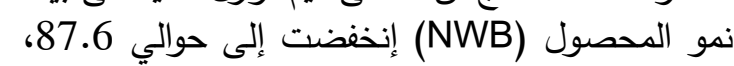

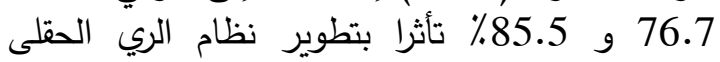

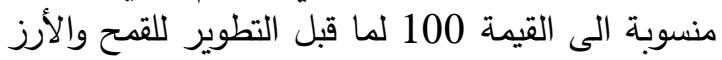

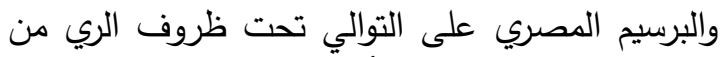

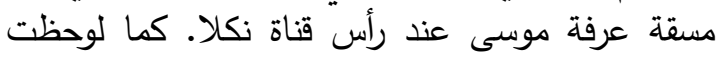

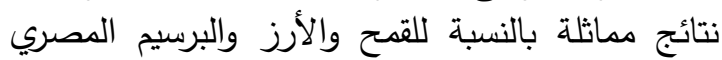

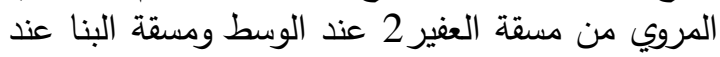
ذيل قناة نكلا.

أظهرت النتائج أن كمية الأملاح المضافة (SA)

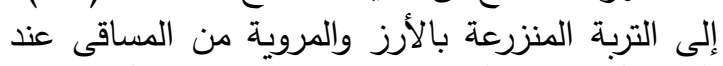

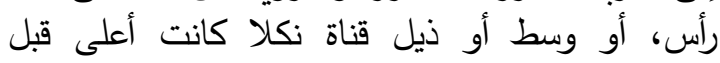

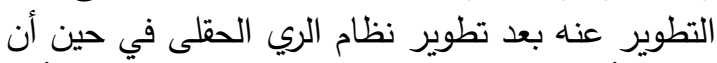

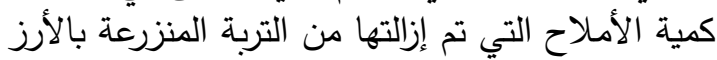
والمروية من المساقى عند رأس، أو وسط أو أو ذيل التيل قناة

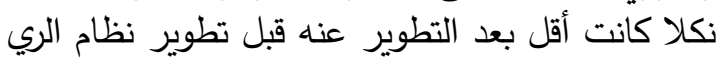

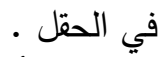
يمكن أن نخلص إلى أن تطوير نظام الري الحقلى

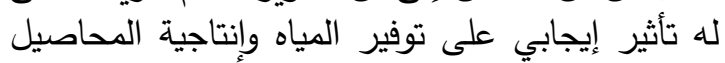

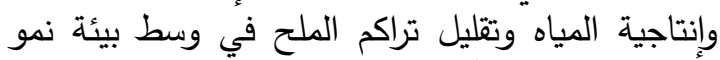

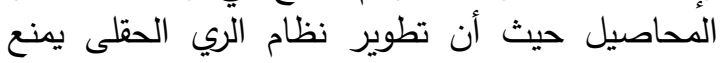

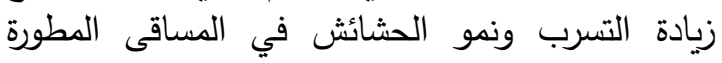

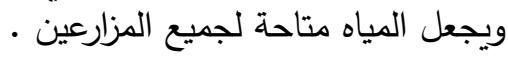

الكلمات الدالة: تطوير الري على الاتزان، الماء

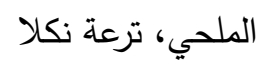

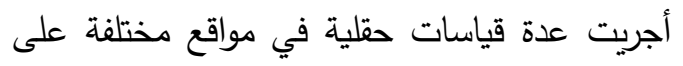

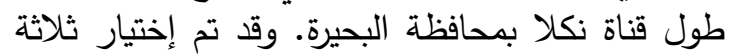

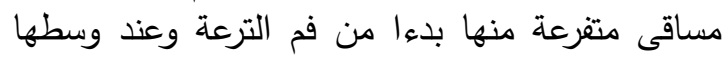

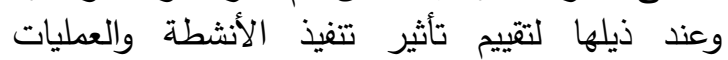

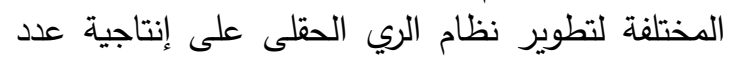
من المحاصيل المنزرعة بالمنطقة وتروى من ترعة نكلة النائة

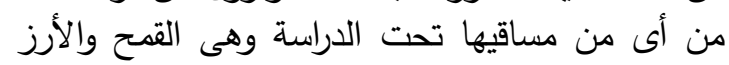

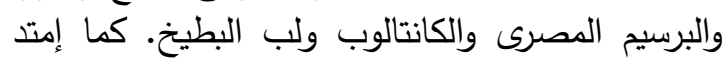
التقييم الى مدى توفير مياه الرى وإنتاجية وحدة الميانياه

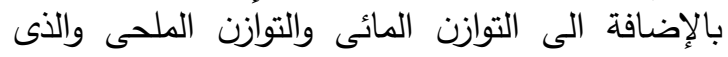

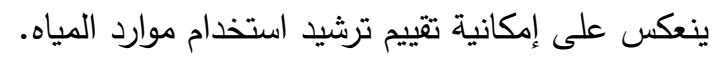

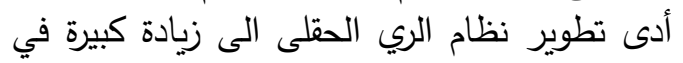

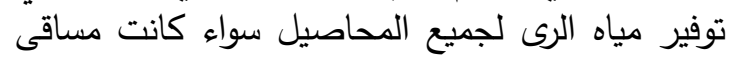
الرى عند رأس أو وسط أو ذيع التيل الترعة بعد التطوير .

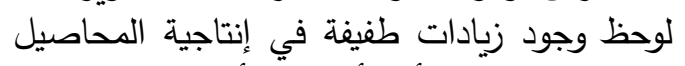
سواء كانت تروى من رأس أو وسط أو ذيل أنسا الترعة التعد

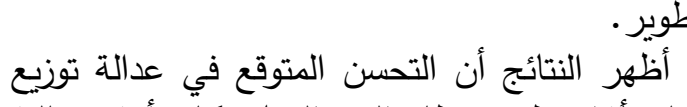
المياه تأثرا بتطوير نظام الري الحقلى كان الكتئ أكثر فعالية

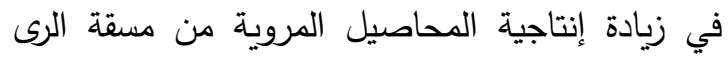
عند ذيل ترعة نكلا، وكانت هذه الزيادة في النيادية إنتاجية

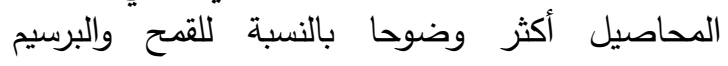

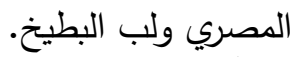

أوضحت النتائج وجود زيادة واضحة في في إنتاجية مياه الرى المضافة لرى جميع المحاصيل تحت الدراسة
تحكيم: ا.د عبدالغني الجندي

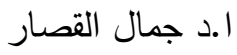
1.د أحمد عبدال الفتاح إبراهيم 
